\title{
RAKOV ŠKOCJAN KARST VALLEY
}

\author{
P. Habił, R. Gospodarič
}

\section{ZEL ̌̌E CAVE (ZEL ĽKE JAME)}

A very specific karst depression, some kind of uvala with $2,5 \mathrm{~km}$ long and 200 wide valley ( $500 \mathrm{~m}$ alt.) of the Rak brook is situated at the northern foot of Javorniki mountain $(1264 \mathrm{~m})$, somewhere in the middle between the Cerknica and Planina polje, carved in a plateau of height $580 \mathrm{~m}$ to $710 \mathrm{~m}$.

At the eastern, spring side, the valley is canyon like. The Rak brook springs up from the Zelß̌ke Jame, numerous collapse dolines being situated around the entrance to the cave. ZelY̌ke Jame consist of the Southern Channel (Juzni Rov), Cold Channel (Mrzli Rov), Nothern Channel (Severni Rov), Water Channel (Vodni Rov), and the rapids of the river Rak (Fig. 1).

The Southern Channel consists of morphologically differing chambers that contain different sediments, yet all having the same speleogenesis. In the wide Silver Hall (Srebrna Dvorana), the walls are covered with many droplets of condesed water which change the firm sinter of stalactites and stalagmites into a soft mass. Interesting hieroglyphs can be found in the Blind Channel (Slepi Rov). Chemical analyses have shown that they are not formed of the loam from the alluvium which covers the floor and lies along the walls as well.

In the Chamber of Curved Pillars (Dvorana Zavitih Stebrov) the air current has created unusual pillars made of sinter. The ascending Staircase Channel (Stopničasti Rov) extends along the faults N-S, once in the dolomitic breccia, another time in pure limestone. The rocky stairs were formed by the former water current which flew northwards. In the Hall of Arches (Dvorana Obokov) and in the Corridor of Pans (Hodnik Ponvic) traces can be found of the hollowing through erosion, of alluviation, corrosion, deposition of sinter, the washing away of the sediments, and of the collapse of the floor. These processes of decay help us conceive the evolution of the cave. Less sinter, but more loam can again be found in the Muddy 


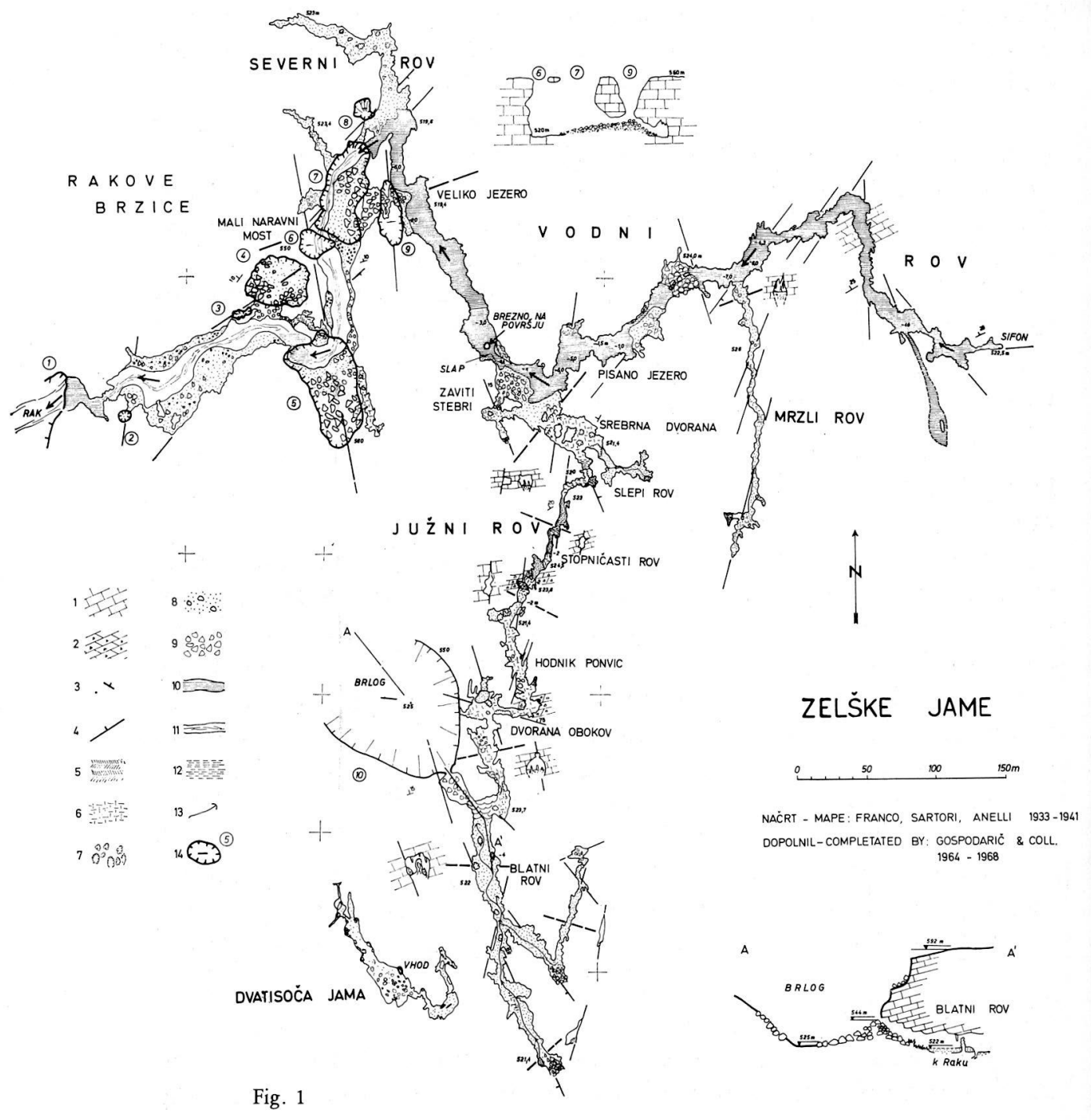


Channel (Blatni Rov) into which the sinking river penetrates several times yearly, carrying away the loamy alluvium and exposing gradually the rocky from the channel. Such an alluvium hides the connection with Two Thousandth Cave (Dvatisoča Jama) which is some $20 \mathrm{~m}$ distant. The Muddy Channel (Blatni Rov) end in breakdown material and siphon. All attempts which have been made so far to dig away this material or to reach the other end of the siphon by diving have been unsuccessful.

The Water Channel (Vodni Rov) begins with a siphon which is $18 \mathrm{~m}$ deep; through it the water comes from the Large Karlovica (Velika Karlovica), ponor of Cernica lake. Half of the channel is filled with water. Along the walls we find reamins of Pleistocene sediments. The sinking river had carried away the alluvium and is now hollowing the rocky floor.

At the very spring and in one of collapse dolines saw mills were situated a century ago, the rests of them being recognizeable now only.

\section{RAK VALLEY AND NATURAL BRIDGES}

The most spectacular phenomen in spring part of valley is the Small Natural Bridge. It is $5 \mathrm{~m}$ thick rest of the cave roof, its arch being about 40 $\mathrm{m}$ above the Rak brook level.

$500 \mathrm{~m}$ downstream from the Zelške Jame the valley widens and some small affluents join Rak from the south. Much more important spring is Kotlici, where water from Cerkniško polje appear, as well as in Zelške Jame. Near Kotliti is a small collapse, named Kotel, where high waters appear only. The wide loamy and sandy flat along the lower course of the Rak is concluded after $800 \mathrm{~m}$ by the Great Natural Bridge. A road is constructed over it and ruins of the St. Cancian church are situated there too.

Rak underpasses through $12 \mathrm{~m}$ wide and $15 \mathrm{~m}$ high tunnel cave into a $150 \mathrm{~m}$ long canyon with perpendicular walls. On the other side of this spectacular collapse Rak sinks into the Škocjanska Jama or Tkalca Jama. Some water sinks before the bridge on both sides of course already. The short distance from this point to the springs at Planina polje is about $4 \mathrm{~km}$.

\section{TKALCA CAVE}

The Tkalca Jama has two entrances. The larger one is the direct continuation of the Rak Canyon, while the smaller one is a window like opening about $200 \mathrm{~m}$ from the Great Natural Bridge. Beyond the voluminous entrance room the Rak course forks into two branches, that are interrupted after a few hundred metres by siphons. The right one $(150 \mathrm{~m}$ long, $30 \mathrm{~m}$ 


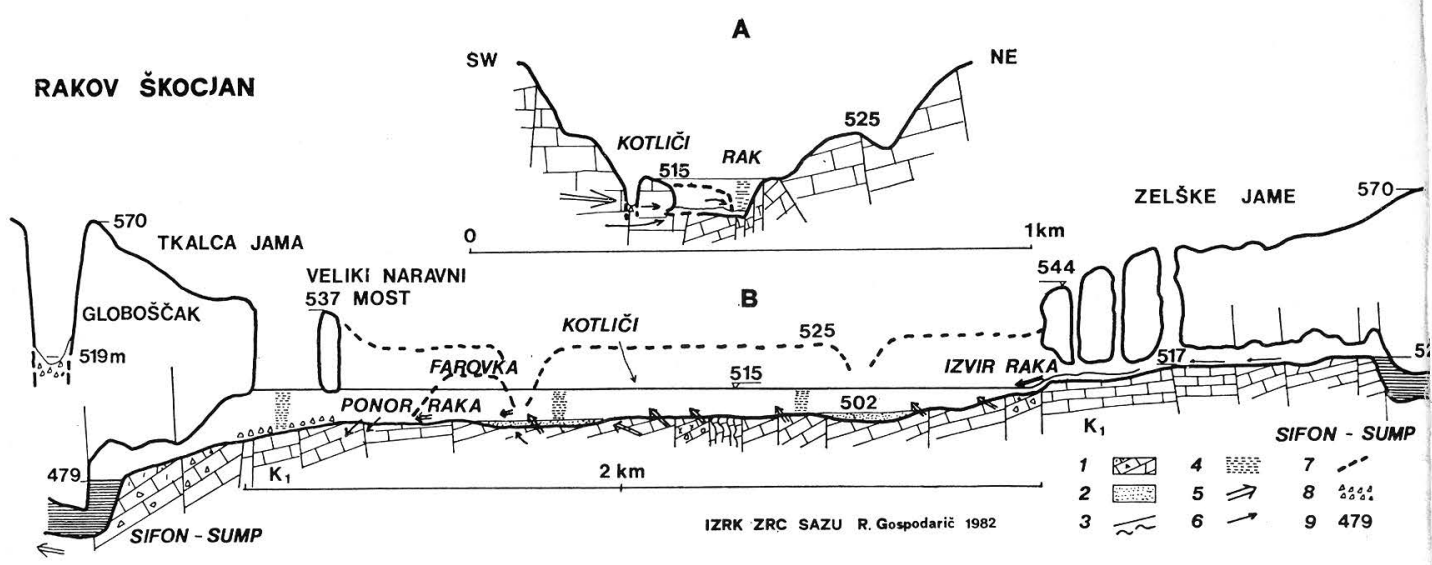

Fig. 2

deep) was explored by divers and they discovered an about $2 \mathrm{~km}$ long water channel. It is interrupted by another siphon and there are still about 2 $\mathrm{km}$ of unexplored passages between it and the Rak fork of Planinska Jama (Fig. 2).

North from the Great Natural Bridge the bottom of uvala is rocky, without superficial water and pitted with numerous dolines. The terrain is gently sloping towards the pass near uvala Unec ( $570 \mathrm{~m}$ a.s.l.). Different terrace like flats on the sides of the Rak valley, more than $10 \mathrm{~m}$ thick layer of fluvial sediments at the bottom and numerous collapse dolines on the both sides, testimony a polygenetic origin of this karst depression.

\section{GEOLOGICAL SETTING}

An important role in its formation played the geological and tectonical setting along the Idrija fault and the Javorniki rised block. The karst waters, flowing underground from Cerkniško Jezero towards Planinsko polje riched the surface here and a pictoresque karst valley appeared. It is formed in lower Cretaceous, mycritic limestones, belonging to the Javorniki-Snežnik overthrust unit. Sedimentary breccias with sandy dolomites and limestones cement appear somewhere in the limestone masses. The strate dip 30 degrees towards W, SW, and NW, and so, the oldest rocks are found on the eastern side of the valley. The rock is densely fracturated due to a distinctive tectonical zone, running along the central and 


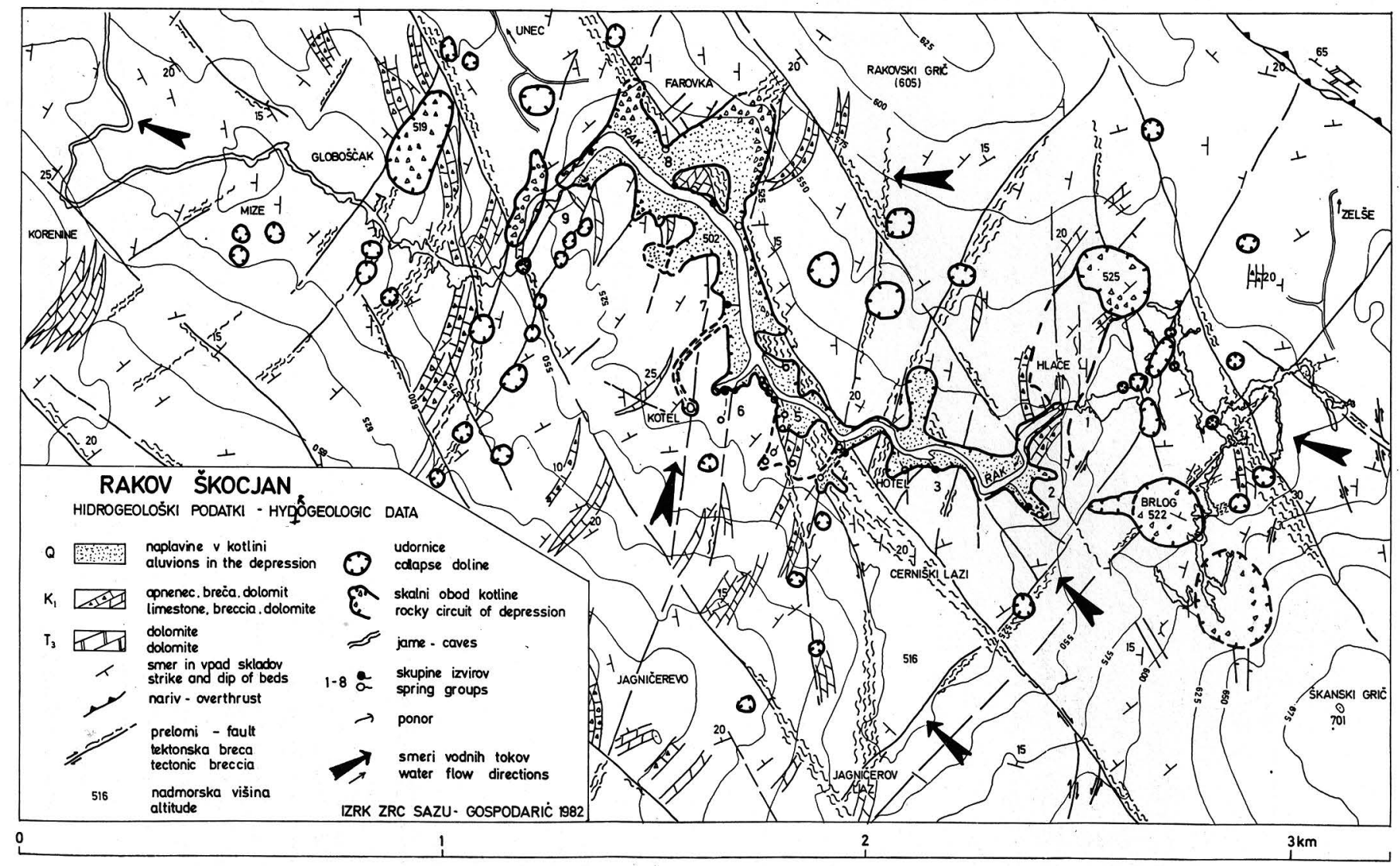

Fig. 3 
lover part of the valley. This zone is hydrologically important as well, the springs being situated on its eastern side and the ponors on the western one. The only exception are the Kotlici springs, relating to another tectonical unit (Fig. 3).

\section{WATER REGIME OF RAK BROOK}

The water regime in the Rak valley is intimately bound to the regime in Carkniško polje. When the lake dries up, the course of Rak extincts too, some water remaining preserved in the alluvium bed and in the spring pools. At the time of high waters, normally in the cold half of the year, discharge of Zelske Jame is about $25 \mathrm{~m}^{3} / \mathrm{s}$, as well as Kotli $\mathrm{X}_{\text {. The Tkalca Ja- }}$ ma can take about $30 \mathrm{~m}^{3} / \mathrm{s}$ only and so a $10 \mathrm{~m}$ deep lake appears in the valley. The arch of Great Natural Bridge becomes nearly flooded. The connections of Rak with the Cerknisko Jezero, or with the springs at Planinsko polje are proved by watertracing. The velocities of underground waters are from $0,1 \mathrm{~cm} / \mathrm{s}$ to $8 \mathrm{~cm} / \mathrm{s}$. The water of Rak is relatively warm in the summer $\left(20^{\circ} \mathrm{C}\right)$ and cold in winter, as a consequence of direct connection with Cerkniško polje (lake). The planned barrage of the Cerkniško polje and construction of tunnels to the hydroelectric plant at Planinsko polje would change essentially the water regime in the Rakov Skocjan.

\section{REFERENCE}

Man's impact in Dinaric Karst. Guide Book. Edited by I. Gams, P. Habič, IGU, Study group, Ljubljana, 1987, p. 80-87. 